\title{
Dietary risk assessment of fluoride, lead, chromium, and cadmium through consumption of Tieguanyin tea and white tea
}

\author{
Qinghua $\mathrm{YAO}^{1 \star}$ (D), Qiu LIN ${ }^{1}$, Sun-an YAN ${ }^{1}$, Minmin HUANG ${ }^{1}$, Lihua CHEN ${ }^{1}$
}

\begin{abstract}
Food and beverage consumption is the most possible route of human exposure to undesirable elements. Tieguanyin tea and white tea are widely-consumed beverage, which may be contaminated by fluoride (F), lead $(\mathrm{Pb})$, chromium $(\mathrm{Cr})$, and cadmium (Cd). For this study, the contamination levels and dietary exposure risks of these elements were studied from 72 Tieguanyin tea samples and 40 white tea samples from Fujian Province, China. The average concentrations of these elements decreased in order from F, Pb, Cr to Cd in Tieguanyin tea, while white tea in order from F, Cr, $\mathrm{Pb}$ to Cd. Metal-to-metal correlation indicated a weak positive correlation between $\mathrm{Pb} / \mathrm{Cd}$ pairs (Tieguanyin tea) and $\mathrm{Pb} / \mathrm{Cr}$ pairs (white tea). A weak negative correlation pair was found for $\mathrm{Cr} / \mathrm{Cd}$ in Tieguanyin tea. The hazard index levels were below one, suggesting that there was no significant noncarcinogenic health risk to tea drinking consumers under the current dietary intake. The total cancer risk values of $\mathrm{Pb}, \mathrm{Cd}$, and Cr via the consumption of Tieguanyin tea and white tea were $4.01 \times 10^{-5}$ and $7.64 \times 10^{-6}$, fell into the acceptable range of $10^{-6} \sim 10^{-4}$. It demonstrated that the cancer risk for consumers via drinking Tieguanyin tea and white tea was acceptable.
\end{abstract}

Keywords: tea; fluoride; heavy metals; health risk; cancer risk.

Practical Application: Food and beverage consumption is the most possible route of human exposure to undesirable elements. Due to potential pollution in plantation and processing procedures, tea may be contaminated with fluoride, lead, chromium, and cadmium. This situation may cause the emergence of many serious problems in terms of human health such as anemia, cancer, and miscarriages. Therefore, monitoring and health risk assessment of tea are in an urge.

\section{Introduction}

As the second most popular non-alcoholic beverage around the world, after water, tea (Camellia sinensis) is an important agricultural product for export in China (Yi et al., 2013; Zhang et al., 2017a). Depending on the fermentation process, teas are classified into three main categories, i.e. unfermented green tea, semi-fermented oolong tea and fermented black tea (Malinowska et al., 2008; Zhao et al., 2011; Yen et al., 2013; Castañeda-Saucedo et al., 2020). Compared to all other teas, white tea is produced in a special way, including only withering and drying processes without enzyme deactivation or fermentation (Chen et al., 2019; Dai et al., 2017; Ning et al., 2016). Because this simplest process, the high concentrations of catechins, amino acids, and other constituents are retained in white tea (Chen et al., 2019; Tian \& Huang, 2019; Zhang et al., 2019; Ning et al., 2016). For another tea (Tieguanyin tea), though with high degree of fermentation, it is famous for the unique and elegant floral aroma, and ripe fruity flavor (Zhou et al., 2019; $\mathrm{Xu}$ et al., 2018). Both Tieguanyin tea and white tea are famous around the world and are mainly produced in Fujian Province (Li et al., 2014; Ning et al., 2016).

At present, the consumers are concerned about the chemical contaminants in food and beverages due to their potential toxicity to humans (Lv et al., 2013; Jiang et al., 2019). This issue has also received more attention concerning tea as the use of agro chemicals has increased over the past decades (Karak \& Bhagat,
2010; Pehrsson et al., 2011; Yaqub et al., 2018). Fluoride, one of the most chemically active elements occurring in nature, exhibits both beneficial and toxic effects on human health (Janiszewska \& Balcerzak, 2013; Chan et al., 2013). The tea plant (Camellia sinensis) takes up fluoride from soil and accumulates fluoride in its leaves (Fung et al., 1999). Sha \& Zheng (1994) reported that $98 \%$ of fluoride in the whole tea plant were accumulated in tea leaves. Due to tea contains a very high quantity of fluoride and the transfer rate of fluoride during tea infusion is nearly $100 \%$ (about 94.9\%) (Fung et al., 1999), tea is considered as the main natural source of fluoride intake (World Health Organization, 1984). And it has long been considered beneficial for the prevention of dental problems (Goenka et al., 2013). However, several studies have reported that the fluoride intake is one of the greatest potential health risks for tea consumers when its concentration exceeds a critical range (Emekli-Alturfan et al., 2009; Chan et al., 2013; Lv et al., 2013). Many studies show excessive fluoride intake may increase the incidence of dental fluorosis and skeletal fluorosis (Cao et al., 2005; Baskaradoss et al., 2008; Malinowska et al., 2008). There is even literature showing that exposure to fluoride may be a possible cause of cancer (Takahashi et al., 2001; Chan et al., 2013). The presence of toxic heavy metals (e.g., lead, chromium, cadmium) are other major concerns. During the growing and processing procedures, tea may be contaminated with heavy metals (Cao et al., 2010; Ning et al., 
2011). Moreover, rainfall, dust, and fertilizers also may be the sources of the heavy metal content in tea (Nkansah et al., 2016). According to previous research, the presence of heavy metals in some tea infusions exceeds the maximum limits recommended by different organizations or countries, which could pose a variety of health risks such as anaemia, cancer, and miscarriages (Salahinejad \& Aflaki, 2010; Karak \& Bhagat, 2010; Lv et al., 2013; Roya \& Ali, 2017).

In the last decade, considerable research has been conducted on the fluoride and heavy metal content of brick tea (Koblar et al., 2012; Lv et al., 2013; Zhang et al., 2017b), black tea (Koblar et al., 2012; Dambiec et al., 2013; Waugh et al., 2017; Zhang et al., 2017b), oolong tea (Koblar et al., 2012; Zhang et al., 2017b), and green tea (Koblar et al., 2012; Zhang et al., 2017b). However, little data on the fluoride and heavy metal content in Tieguanyin tea and white tea are available, and information about their health risk assessment can thus not be found. Therefore, it is necessary to determine and analyze the magnitude of contamination by these elements in Tieguanyin tea and white tea from their major production areas. And risk assessment is needed to verify the current status of these undesirable elements.

The aims of this study were to (1) determine fluoride, lead, chromium, and cadmium concentrations in Tieguanyin tea and white tea from Fujian Province, China; (2) explore the correlation of the heavy metals with the Pearson correlation matrix; and (3) assess the potential risks fluoride and those heavy metals pose to consumer health.

\section{Materials and methods}

\subsection{Samples collection and preparation}

A total of 112 tea samples ( $500 \mathrm{~g}$ each), including 72 Tieguanyin tea samples and 40 white tea samples were randomly collected from the major producing counties [Anxi $\left(24^{\circ} 50^{\prime}-25^{\circ} 26^{\prime} \mathrm{N}\right.$; $\left.117^{\circ} 36^{\prime}-118^{\circ} 17^{\prime} \mathrm{E}\right)$, Hua'an $\left(24^{\circ} 38^{\prime}-25^{\circ} 12^{\prime} \mathrm{N} ; 117^{\circ} 16^{\prime}-117^{\circ} 42^{\prime} \mathrm{E}\right)$ and Fuding $\left(26^{\circ} 52^{\prime}-27^{\circ} 26^{\prime} \mathrm{N}\right.$; $119^{\circ} 55^{\prime}-120^{\circ} 43^{\prime} \mathrm{E}$ )] (Figure 1) by the agricultural bureau in the counties involved. The sampling was done according to guideline in China (Standardization Administration of China, 2013). An amount of $200 \mathrm{~g}$ of each tea sample was ground and passed through a $200 \mu \mathrm{m}$ polyethylene sieve. All the powdered tea samples were stored in separate polyethylene container at $4{ }^{\circ} \mathrm{C}$ until analysis.

\subsection{Chemicals and reagents}

All chemical products used were of analytical reagent grade unless otherwise stated. Ultrapure water was obtained using a Direct-Q3 UV water system (18.25 $\mathrm{M} \Omega \mathrm{cm}^{-1}$, Millipore, Bedford, MA, USA) for all dilutions and blanks. Hydrochloric acid $(\mathrm{HCl}$, $37 \%$, Analytical reagent) and nitric acid $\left(\mathrm{HNO}_{3}, 65 \%\right.$, guaranteed reagent) were provided from Xilong Chemical Co., Ltd. (Shantou, Guangdong, China). The calibration curves were prepared using dilutions of $\mathrm{F}, \mathrm{Pb}, \mathrm{Cr}, \mathrm{Cd}$ standard solution (Guobiao Testing \& Certification Co., Ltd., Beijing, China). Tea certified reference material (GBW10016, Institute of Geophysical and Geochemical Exploration, China) was used for quality assurance.

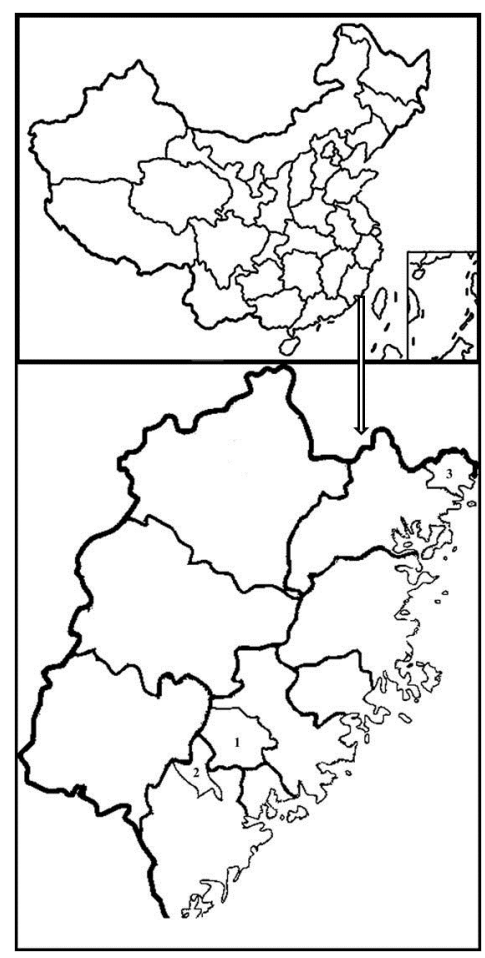

Figure 1. Production of areas of Tieguanyin tea and White tea in Fujian province of China: (1) Anxi; (2) Hua'an; (3) Fuding.

\subsection{Determination of fluoride}

The total fluoride content in the tea samples was analyzed according to the standard method for analysis of fluoride in food (Standardization Administration of China, 2003). Briefly, $1.000 \mathrm{~g}$ tea sample was extracted by $10 \mathrm{~mL}$ of $0.2 \mathrm{M}$ $\mathrm{HCl}$ for $1 \mathrm{~h}$ with occasional gentle shaking. The extract of tea samples or $\mathrm{F}$ standard solution was added to $25 \mathrm{~mL}$ total ionic strength adjusting buffer, then de-ionized water was added up to $50 \mathrm{~mL}$. A fluoride ion-selective electrode (INESA Scientific Instrument Co., Ltd., Shanghai, China) was used to measure the fluoride content. Prior to sampling and at the end of group of five samples, the electrode was re-checked for accuracy. The reliability of the method was certified by standard reference material of tea (GBW10016). The agreement between results and the certified values was satisfactory, the mean recovery was $94 \%$ with a standard deviation (SD) $8 \%$. Three replicates of each tea sample undergoing the same procedures were performed. Data are expressed on a dry weight (DW) basis.

\subsection{Determination of lead, chromium, and cadmium}

Inductively coupled plasma mass spectrometry (ICP-MS) (XSERIES 2, Thermo Fisher Scientific Co., Ltd., MA, USA) was used for determination of $\mathrm{Pb}, \mathrm{Cr}, \mathrm{Cd}$ according to previous research (Han et al., 2005; Lv et al., 2013). All glassware was kept in the $10 \% \mathrm{HNO}_{3}$ solution and rinsed with ultra-pure water, then air dried before use. A microwave digestion system (TOPEX, Preekem Scientific Instruments Co. Ltd., Shanghai, China) was applied for sample digestion. About $0.5 \mathrm{~g}$ of each tea sample was weighed and $5 \mathrm{~mL}$ of high purity $\mathrm{HNO}_{3}$ was added. The mixture was left at room temperature for $15 \mathrm{~min}$ and then 
placed in the microwave oven for $10 \mathrm{~min}$ at a maximal pressure of $800 \mathrm{psi}$ and $170^{\circ} \mathrm{C}$ temperature. After digestion and cooling, each solution was evaporated to near dryness and transferred into a $25 \mathrm{~mL}$ volumetric flask. The solution was topped up to the mark using de-ionized water and transferred into a PTFE bottle, ready for ICP-MS analysis. The mean recoveries for these 3 elements ranged from $90 \%$ to $115 \%$, with a standard deviation (SD) lower than $10 \%$. The limits of detection (LOD) of $\mathrm{Pb}, \mathrm{Cd}$, and Cr were $0.005,0.001$, and $0.05 \mathrm{mg} / \mathrm{kg}$, respectively. The accuracy and ICP-MS instrument performance were evaluated by the tea certified reference material (GBW10016). A blank digestion solution was made for comparison. All samples were measured in triplicate. Data are expressed on a dry weight (DW) basis.

\subsection{Statistical analyses}

Statistical analysis of data was performed with SPSS (Statistical Package for Social Sciences) version 20 for Windows (SPSS Inc., Chicago, IL, USA). Results were expressed as the mean \pm standard deviation (SD). Mean concentrations of each element in different origins or varieties were evaluated for significance by one-way analysis of variance (ANOVA). A statistically significant difference between different sets of data was defined as a value of $p<0.05$. The Pearson's correlation matrix was used to analyze the relationships between heavy metal concentrations. It is useful for indicating the pollutants' probable common source.

\subsection{Health risk assessment}

The potential health risk, including non-cancer health risk and target cancer risk via drinking tea infusion for adults, were assessed as reported by Castro-González et al. (2019) and Bortey-Sam et al. (2015). The non-cancer health risk was performed by calculating the target hazard quotient (THQ), by dividing the chronic daily intake (CDI) with the oral reference dose $(R f D)$ (Equation 1, Equation 2).

$$
C D I=(C \times D \times T) \div B w
$$

where $\mathrm{C}$ is the average content $\left(\mu \mathrm{g} \mathrm{kg}^{-1}\right)$ of a trace element in tea, $\mathrm{D}$ is the amount of tea consumed, $\mathrm{T}$ is the transfer rate of a trace element from made tea to tea infusion and $\mathrm{Bw}$ is the average body weight.

$$
T H Q=C D I / R f D
$$

where RfD values of the trace elements were obtained from the US Environmental Protection Agency (USEPA) or the Joint FAO/WHO Expert Committee of Food Additives (JECFA), which are given in Table 1. A hazard index (HI), sum of THQ (Equation 3), was obtained to determine the overall potential risk of $\mathrm{Pb}, \mathrm{Cd}$ and $\mathrm{Cr}$.

$$
H I=\sum T H Q
$$

If the $\mathrm{HI}$ value is above or equal to 1 , this indicates an unacceptable health risk for human health (Khan et al., 2013; United States Environmental Protection Agency, 2016).
Table 1. Oral reference dose $(R f D)$ values and slope factors $(S f)$ of the metals considered to be carcinogenic.

\begin{tabular}{ccc}
\hline Trace elements & $R f D\left(\mu \mathrm{g} \mathrm{kg}^{-1} \mathrm{day}^{-1}\right)$ & $S f\left(\mathrm{mg} \mathrm{kg}^{-1} \mathrm{day}^{-1}\right)$ \\
\hline $\mathrm{F}$ & 4000 & - \\
$\mathrm{Pb}$ & $3.57^{\mathrm{a}}$ & $0.0085^{\mathrm{b}}$ \\
$\mathrm{Cr}$ & 3 & 0.5 \\
$\mathrm{Cd}$ & 1 & 6.1 \\
\hline
\end{tabular}

${ }^{\mathrm{a}} \mathrm{Pb}$ is set at $3.57 \mathrm{ug} \mathrm{kg}^{-1}$ day $^{-1}$ according to provisional tolerable daily intake (PTDI) suggested by $\mathrm{FAO} / \mathrm{WHO}$, since the $\mathrm{RfD}$ for $\mathrm{Pb}$ in USEPA is not available. ${ }^{\mathrm{b}} \mathrm{Cd}, \mathrm{Cr}$ are the heavy metals considered to be carcinogenic and $\mathrm{Pb}$ is probably carcinogenic.

Target cancer risk (TR) was used to indicate carcinogenic risks from the consumption of tea. The model for estimating TR was shown as follows (Equation 4):

$T R=C D I \times S f$

where $S f$ is the slope factors of the heavy metals considered to be carcinogenic. The total cancer risk $\left(\mathrm{TR}_{\text {total }}\right)$ was calculated as (Equation 5):

$T R_{\text {total }}=\sum T R$

\section{Results and discussion}

\subsection{Contaminant levels of fluoride, lead, chromium, and cadmium in tea}

The analytical results of 112 tea samples collected from different areas of Fujian Province are summarized in Table 2. Concentration of the elements analyzed were in the range $48-580 \mathrm{mg} \mathrm{kg}^{-1}$ for F, $0.18-2.00 \mathrm{mg} \mathrm{kg}^{-1}$ for Pb, $0.08-2.30 \mathrm{mg} \mathrm{kg}^{-1}$ for $\mathrm{Cr}$, and $0.01-0.11 \mathrm{mg} \mathrm{kg}^{-1}$ for $\mathrm{Cd}$, respectively. According to this data, $\mathrm{F}$ had the highest concentration, followed by $\mathrm{Pb}, \mathrm{Cr}$, and $\mathrm{Cd}$.

\section{Fluoride}

Fluoride mean contents in tea samples collected from different areas were $190 \mathrm{mg} \mathrm{kg}^{-1}$ (Anxi), $188 \mathrm{mg} \mathrm{kg}^{-1}$ (Hua'an), $142 \mathrm{mg} \mathrm{kg}^{-1}$ (Fuding). The highest content of $\mathrm{F}$ was found in a Tieguanyin tea sample from Huaan and the lowest one was found in a white tea sample from Fuding. The average fluoride concentration in white tea was significantly lower than that in Tieguanyin tea $(p<0.05)$. However, no significant difference was observed between the average fluoride content in Tieguanyin tea from different production areas. A plausible explanation could be the different manufacturing procedure of the white tea in comparison to the Tieguanyin tea (Tan et al., 2017; Sanlier et al., 2018). Tieguanyin tea was often processed from one bud and four or five leaves, while only one bud and three leaves were picked for white tea, and their tea plant varieties were different (Sanlier et al., 2018; Xu et al., 2018). Simultaneously, Tieguanyin tea is semi-fermented and white tea is not fermented. Shu et al. (2003), Malinowska et al. (2008), and Janiszewska \& Balcerzak (2013) revealed that the content of fluoride in tea depends on maturity and the fermentation step of processing. The fluoride content in black tea is generally higher than that of non-fermented 
Table 2.Content of fluoride, lead, chromium and cadmium in tea from Fujian Province of China $\left(\mathrm{mg} \mathrm{kg}^{-1}\right)$.

\begin{tabular}{|c|c|c|c|c|c|c|c|}
\hline \multirow{2}{*}{$\begin{array}{c}\text { Tea type, Area } \\
\text { Elements }\end{array}$} & \multicolumn{2}{|c|}{ Tieguanyin, Anxi $(n=40)$} & \multicolumn{2}{|c|}{ Tieguanyin, Hua'an $(n=32)$} & \multicolumn{2}{|c|}{ White tea, Fuding $(\mathrm{n}=40)$} & \multirow{2}{*}{ Mean \pm SD } \\
\hline & Range & Mean \pm SD & Range & Mean \pm SD & Range & Mean \pm SD & \\
\hline Fluoride & $73-350$ & $190 \pm 78^{\mathrm{b}}$ & $89-580$ & $188 \pm 101^{\mathrm{b}}$ & $48-290$ & $142 \pm 61^{\mathrm{a}}$ & $173 \pm 83^{\mathrm{ab}}$ \\
\hline Lead & $0.31-2.00$ & $0.91 \pm 0.41^{\mathrm{b}}$ & $0.40-1.28$ & $0.81 \pm 0.24^{\mathrm{b}}$ & $0.18-1.69$ & $0.65 \pm 0.37^{\mathrm{a}}$ & $0.79 \pm 0.34^{\mathrm{ab}}$ \\
\hline Cadmium & $0.01-0.11$ & $0.04 \pm 0.03^{\mathrm{b}}$ & $0.01-0.05$ & $0.02 \pm 0.01^{\mathrm{a}}$ & $0.01-0.07$ & $0.03 \pm 0.01^{\mathrm{a}}$ & $0.03 \pm 0.02^{\mathrm{a}}$ \\
\hline
\end{tabular}

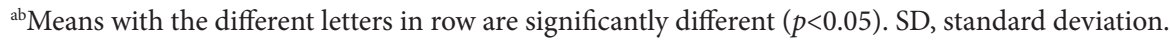

or semi-fermented teas (Shu et al., 2003; Malinowska et al., 2008). Zhang et al. (2017a) also showed that the average contents of fluoride in different types of teas decreased in order from brick tea, to black tea, oolong tea, and green tea. The brick tea produced in Sichuan Province contained high fluoride concentrations with a mean value $491.8 \mathrm{mg} \mathrm{kg}^{-1}$ (Cao et al., 1998). Furthermore, the difference in the mean fluoride concentration between Tieguanyin tea and white tea may be partly associated with soil conditions. It was reported that the plantations' soil conditions and the tea plant varieties should influence the fluoride content in tea (Shu et al., 2003; Lv et al., 2013).

\section{Lead}

Lead levels in tea samples in this study were lowest in a white tea sample collected from Fuding and highest in a Tieguanyin sample from Anxi. The average lead content of tea from different production areas was $0.91 \mathrm{mg} \mathrm{kg}^{-1}$ (Tieguanyin tea, Anxi), $0.81 \mathrm{mg} \mathrm{kg}^{-1}$ (Tieguanyin tea, Huaan), and $0.65 \mathrm{mg} \mathrm{kg}^{-1}$ (white tea, Fuding), respectively. The significantly higher mean lead content for Tieguanyin tea than for that of white tea can be explained by the different types of leaves which are picked for them. With the different tea plant varieties, Tieguanyin tea was processed from one bud and four or five leaves, while white tea was processed from one bud and three leaves (Sanlier et al., 2018; $\mathrm{Xu}$ et al., 2018). Furthermore, older tea leaves tend to contain higher concentrations of lead than younger leaves (Natesan \& Ranganathan. 1990). The previous studies found the lead content in different tea types increase in order from green tea, to black tea, and oolong tea (Han et al., 2006, 2014). Moreover, the processing procedure and storage (e.g. containers) could be other probable sources of the lead content in tea.

\section{Chromium}

The tea samples from Anxi, Hua'an, and Datian showed average $\mathrm{Cr}$ Concentrations of $0.58 \mathrm{mg} \mathrm{kg}^{-1}, 0.54 \mathrm{mg} \mathrm{kg}^{-1}$, and $0.73 \mathrm{mg} \mathrm{kg}^{-1}$, respectively. The highest and the lowest content of $\mathrm{Cr}$ were observed in a Tieguanyin tea sample from Anxi and white tea sample from Fuding. The $\mathrm{Cr}$ content of white tea was higher than that of Tieguanyin tea from Huaan $(p<0.05)$. However, comparison of $\mathrm{Cr}$ content in Anxi and Fuding tea samples showed no significant differences $(p>0.05)$. In a survey done on a total of 801 tea samples in China, the highest mean content of $\mathrm{Cr}$ was found in black tea (Han et al., 2005). Additionally, significant differences were observed between green tea and black tea, as well as black tea and oolong tea (Han et al., 2005). Seenivasan et al. (2008) reported that $\mathrm{Cr}$ content in tea was mainly correlated with the sharpening of crush, tear, and curl rollers used for manufacturing. It has also been reported that $\mathrm{Cr}$ contamination of plants depends on $\mathrm{Cr}$ speciation in soil (Gardea-Torresdey et al., 2004). This could be partly explained by the difference in $\mathrm{Cr}$ concentration in the tea from different production areas.

\section{Cadmium}

The Cd content in Anxi tea samples varied between $0.01 \mathrm{mg} \mathrm{kg}^{-1}$ and $0.11 \mathrm{mg} \mathrm{kg}^{-1}$ with a mean of $0.04 \mathrm{mg} \mathrm{kg}^{-1}$, which was significantly higher than that in tea from Huaan or Fuding $(p<0.05)$. There was no significant difference $(p>0.05)$ between the concentration of $\mathrm{Cd}$ in tea samples from Hua'an and Fuding. Franklin et al. (2005) indicated that cadmium in tea was mainly absorbed from zinc fertilizers and phosphate fertilizers. And the mean concentration of $\mathrm{Cd}$ in this study was lower than $\mathrm{Cd}$ contents in black tea (Ashraf \& Mian, 2008; Nkansah et al., 2016) and green tea (Han et al., 2005; Nkansah et al., 2016). However, the contaminated level of Cd in oolong tea (Han et al., 2005), Pu'er tea (Ning et al., 2011) and green tea (Nookabkaew et al., 2006) were found to be comparable to the present study.

\subsection{Pearson's correlation analysis for lead, chromium, and cadmium}

The Pearson's correlation analysis is a measure of the linear correlation between two variables and shows the results in a matrix form. Pearson's correlation is helpful for showing the direction and strength of the association among variables. The values are between +1 and -1 , where 1 is total positive linear correlation, 0 is no linear correlation, and - 1 is total negative linear correlation. Nkansah et al. (2016) reported that the heavy metals in tea may have a probable common source if the pair of metals has a close relationship. Metal-to-metal correlation coefficient matrix for tea samples is shown in Table 3 . The significantly weak positive correlation was found for $\mathrm{Pb} / \mathrm{Cd}$ pairs $(\mathrm{r}=0.392$, $p<0.01)$ in Tieguanyin tea and $\mathrm{Pb} / \mathrm{Cr}$ pairs $(\mathrm{r}=0.350, p<0.05)$ in white tea, indicating that these heavy metals may have a common pollution source. $\mathrm{Cr}$ concentration in Tieguanyin tea showed a relatively weak negative correlation with $\mathrm{Cd}$ concentration $(\mathrm{r}=-0.297, p<0.05)$. The values of $\mathrm{r}$ for $\mathrm{Pb} / \mathrm{Cr}$ in Tieguanyin tea were not at significant levels $(p>0.05)$. And Cd concentration of white tea also showed no significant correlation with $\mathrm{Pb}$ or $\mathrm{Cr}$ concentration $(p>0.05)$. A similar study of Nkansah et al. (2016) showed $\mathrm{Cd} / \mathrm{As}$, and $\mathrm{Pb} / \mathrm{As}$ in tea from Ghana of may have a probable common source. In general, the mechanism of heavy metal enrichment in tea is complex and is related to soil physicochemical properties of the tea plantations, the age of tea trees, the elements' properties and speciation (Jin et al., 
2005; Yemane et al., 2008). Furthermore, tea could be also contaminated by heavy metals during the processing procedure (Qin \& Chen, 2007). Hence, research should be conducted in the future to find out the clear sources of these trace elements in Tieguanyin tea and white tea.

\subsection{Health risk assessment}

\section{Non-cancer health risk}

The health risk assessment was only performed for adults due to children rarely having the habit of drinking tea. As with other beverage crops, water infusion is the main form of tea consumption. Therefore, the transfer rate of trace elements from processed tea leaves to tea infusion needs to be considered when calculating the actual risk of them on human health. In the present study, the transfer rates of $\mathrm{F}, \mathrm{Pb}, \mathrm{Cr}$, and $\mathrm{Cd}$ from made tea to tea infusion were quoted from the previous reports (Table 4).

The CDI values of trace elements through the consumption of Tieguanyin tea or white tea are presented in Table 4 . The CDI values of trace elements in Tieguanyin tea decrease in order from $\mathrm{F}$ to $\mathrm{Pb}, \mathrm{Cr}$, and $\mathrm{Cd}$, while in white tea in order from $\mathrm{F}$ to $\mathrm{Cr}, \mathrm{Pb}$, and $\mathrm{Cd}$. The THQ values of each trace element were below one, indicating that the daily intake of each trace element content in Tieguanyin tea or white tea has no significant potential health risk to a normal adult, which is similar to many other teas assessed by former studies (Shen \& Chen, 2008; Cao et al., 2010; Zhang et al., 2018). The trend of THQ values of individual trace elements via the consumption of Tieguanyin tea and white tea decreased in the order of $\mathrm{Pb}, \mathrm{Cr}, \mathrm{F}, \mathrm{Cd}$, and $\mathrm{F}, \mathrm{Cr}, \mathrm{Pb}, \mathrm{Cd}$, respectively. As shown in Table 4, the $\mathrm{HI}$ value was calculated to assess the combined non-carcinogenic effects of $\mathrm{F}, \mathrm{Pb}, \mathrm{Cr}$, and $\mathrm{Cd}$. The HI value of $4.53 \times 10^{-2}$ was found for Tieguanyin tea,

Table 3. Pearson correlation coefficients among metal concentrations $(r=95 \%)$.

\begin{tabular}{cccccccc}
\hline & \multicolumn{3}{c}{ Tieguanyin } & & \multicolumn{3}{c}{ White tea } \\
\cline { 2 - 4 } \cline { 6 - 8 } & $\mathrm{Pb}$ & $\mathrm{Cr}$ & $\mathrm{Cd}$ & & $\mathrm{Pb}$ & $\mathrm{Cr}$ & $\mathrm{Cd}$ \\
\hline $\mathrm{Pb}$ & 1.000 & 0.173 & $0.392^{* *}$ & & 1.000 & $0.350^{*}$ & -0.150 \\
$\mathrm{Cr}$ & & 1.000 & $-0.297^{*}$ & & 1.000 & -0.276 \\
$\mathrm{Cd}$ & & & 1.000 & & & 1.000 \\
\hline
\end{tabular}

${ }^{\star}$ Correlation is significant at the 0.05 level (two-tailed); ${ }^{* \star}$ Correlation is significant at the 0.01 level (two-tailed). and $1.31 \times 10^{-2}$ for white tea. Both were far below one, indicating that there was no significant non-carcinogenic health risk to tea consumers (Fu et al., 2014; Nkansah et al., 2016).

\section{Target carcinogenic risk of $\mathrm{Pb} / \mathrm{Cr} / \mathrm{Cd}$}

Aside from non-carcinogenic health risks, some heavy metal elements, such as $\mathrm{Cr}$ and $\mathrm{Cd}$, are also carcinogenic. $\mathrm{Pb}$ is probably carcinogenic (Castro-González et al., 2019). The cancer slope factors of $\mathrm{Cr}, \mathrm{Cd}$, and $\mathrm{Pb}$ are shown in Table 1. The carcinogenic risk as a result of the consumption of Tieguanyin tea in this study, based on the individual effects of $\mathrm{Pb}, \mathrm{Cr}, \mathrm{Cd}$, showed that $\mathrm{Cr}$ had the highest target cancer risk (TR) value of $2.23 \times 10^{-5}$, followed by $\mathrm{Cd}$ and the least by $\mathrm{Pb}$ (Figure 2). Meanwhile, the carcinogenic risk of individual effects of heavy metals in white tea was in the order of $\mathrm{Cr}>\mathrm{Pb}>\mathrm{Cd}$. The total target carcinogenic risk $\left(\mathrm{TR}_{\mathrm{total}}\right)$ of $\mathrm{Pb}, \mathrm{Cr}$ and $\mathrm{Cd}$ via the consumption of Tieguanyin tea and white tea are $4.01 \times 10^{-5}$ and $7.64 \times 10^{-6}$, which fall into the acceptable range of $10^{-6} \sim 10^{-4}$ as given by the United States Environmental Protection Agency (2002), demonstrating that the cancer risk of tea consumption was acceptable (Li et al., 2013; Bamuwamye et al., 2015).

In fact, several other uncertain factors may also affect chronic trace elements intake. For example, there are many other exposure ways on health risk, such as food, skin contact and other harmful elements (e.g. arsenic, aluminum, and mercury).

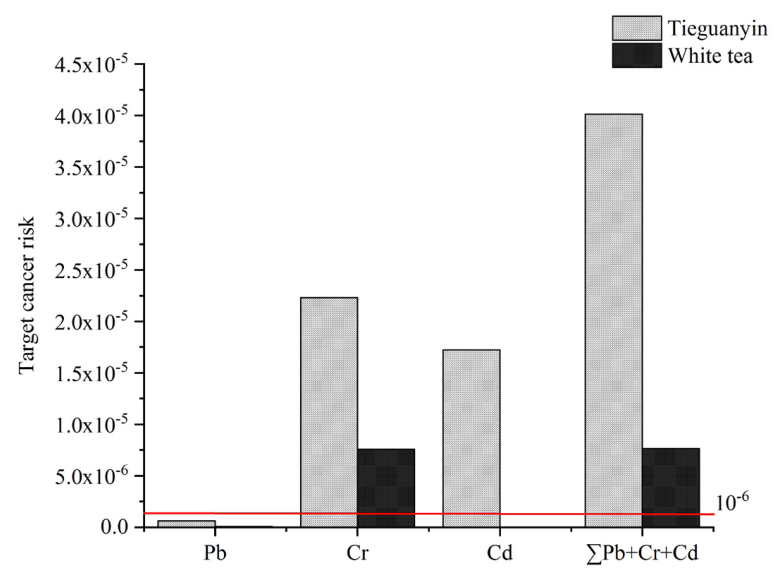

Figure 2. Target cancer risk and Total target cancer risk index in consumers due to consumption of tea.

Table 4. Transfer rate, average content (C), chronic daily intake (CDI) and THQ of 4 elements in tea from Fujian Province of China.

\begin{tabular}{|c|c|c|c|c|c|c|c|c|}
\hline & \multicolumn{4}{|c|}{ Tieguanyin } & \multicolumn{4}{|c|}{ White tea } \\
\hline & Fluoride & Lead & Chromium & Cadmium & Fluoride & Lead & Chromium & Cadmium \\
\hline Transfer rate $(\%)^{\mathrm{a}}$ & 94 & 50.1 & 47.5 & 52.7 & 100 & 7.1 & 12.4 & ND \\
\hline $\mathrm{C}\left(\mathrm{mg} \mathrm{kg}^{-1}\right)$ & 189 & 0.86 & 0.56 & 0.03 & 142 & 0.65 & 0.73 & 0.03 \\
\hline $\mathrm{CDI}^{\mathrm{b}}\left(\mu \mathrm{g} \mathrm{kg}^{-1}\right.$ bw day $\left.{ }^{-1}\right)$ & 29.68 & $7.19 \times 10^{-2}$ & $4.46 \times 10^{-2}$ & $2.82 \times 10^{-3}$ & 23.68 & $7.73 \times 10^{-3}$ & $1.52 \times 10^{-2}$ & - \\
\hline THQ & $7.42 \times 10^{-3}$ & $2.02 \times 10^{-2}$ & $1.49 \times 10^{-2}$ & $2.82 \times 10^{-3}$ & $5.92 \times 10^{-3}$ & $2.17 \times 10^{-3}$ & $5.05 \times 10^{-3}$ & - \\
\hline $\mathrm{HI}$ & \multicolumn{4}{|c|}{$4.53 \times 10^{-2}$} & \multicolumn{4}{|c|}{$1.31 \times 10^{-2}$} \\
\hline
\end{tabular}

aThe transfer rates of F, Pb, Cr, and Cd from made tea to tea infusion were quoted from the reports of Shokrzadeh et al. (2008), Shen \& Chen (2008) and Koblar et al. (2012). The transfer rates of these four elements for white tea are not available, so the value for green tea was used; ${ }^{\mathrm{b} A c c o r d i n g}$ to the report of Chen et al. (2015)[66], daily intake of Tieguanyin tea is $10 \mathrm{~g}$ and the adult body weight is $60 \mathrm{~kg}$. ND, not detected. 
And the health risk may increase due to the accumulation of heavy metal elements in the organism. Rasmussen et al. (2001) reported that $\mathrm{Pb}$ remains in the bones for decades. Furthermore, the occurrence forms and valence of heavy metal elements were not considered, so that the evaluation results, calculated with the total exposure dose, were overestimated. Thus, some deviations between the final health risk value and real value remain. As a conclusion, because the health risk through the consumption of Tieguanyin tea or white tea is low, the uncertainties that cause overestimation will not have a big influence on the assessment results.

\section{Conclusion}

This study assessed the health risk of $\mathrm{F}, \mathrm{Pb}, \mathrm{Cr}$, and $\mathrm{Cd}$ in Tieguanyin tea and white tea from Fujian province of China. Significant differences were found in the content of these trace elements in tea from the different production areas. The average concentrations of these four elements in Tieguanyin tea were statistically significantly different compared with white tea $(p<0.05)$. However, no significant differences were observed in the contaminated levels of the studied elements except $\mathrm{Cd}$ in Tieguanyin tea between Anxi and Huảan. The significantly weak positive correlation was found for $\mathrm{Pb} / \mathrm{Cd}$ pairs in Tieguanyin tea and $\mathrm{Pb} / \mathrm{Cd}$ pairs in white tea. $\mathrm{Cr}$ concentration in Tieguanyin tea showed a relatively weak negative correlation with $\mathrm{Cd}$ concentration. The $\mathrm{HI}$ value in tea was below one, indicating the trace elements $(\mathrm{F}, \mathrm{Pb}, \mathrm{Cr}$, and $\mathrm{Cd})$ in Tieguanyin tea or white tea carry no non-carcinogenic health risk to tea consumers. The target cancer risk from exposure to these heavy metals by consuming tea was acceptable as the total target cancer risk $\left(\mathrm{TR}_{\text {total }}\right)$ was lower than the US-EPA management level of $10^{-4}$. These results may provide a reference for tea stakeholders, including risk managers, tea industry, and consumers.

\section{Acknowledgements}

This work was supported by the Project for Risk Assessment of Quality Safety of Agricultural Products in the Ministry of Agriculture (GJFP2018005); the Project for Innovation Team in Fujian Academy of Agricultural Sciences (STIT 2017-1-12); and Natural Science Foundation of Fujian Province (2017J01052);.

\section{References}

Ashraf, W., \& Mian, A. A. (2008). Levels of selected heavy metals in black tea varieties consumed in Saudi Arabia. Bulletin of Environmental Contamination and Toxicology, 81(1), 101-104. http://dx.doi. org/10.1007/s00128-008-9402-0. PMid:18373271.

Bamuwamye, M., Ogwok, P., \& Tumuhairwe, V. (2015). Cancer and non-cancer risks associated with heavy metal exposures from street foods: evaluation of roasted meats in an urban setting. Journal of Environment Pollution and Human Health, 3, 24-30.

Baskaradoss, J. K., Clement, R. B., \& Narayanan, A. (2008). Prevalence of dental fluorosis and associated risk factors in 11-15 year old school children of Kanyakumari District, Tamilnadu, India: a cross sectional survey. Indian Journal of Dental Research, 19(4), 297-303. http://dx.doi.org/10.4103/0970-9290.44531. PMid:19075431.

Bortey-Sam, N., Nakayama, S. M. M., Ikenaka, Y., Akoto, O., Baidoo, E., Yohannes, Y. B., Mizukawa, H., \& Ishizuka, M. (2015). Human health risks from metals and metalloid via consumption of food animals near gold mines in Tarkwa, Ghana: estimation of the daily intakes and target hazard quotients (THQs). Ecotoxicology and Environmental Safety, 111, 160-167. http://dx.doi.org/10.1016/j. ecoenv.2014.09.008. PMid:25450929.

Cao, H., Qiao, L., Zhang, H., \& Chen, J. (2010). Exposure and risk assessment for aluminium and heavy metals in Puerh tea. The Science of the Total Environment, 408(14), 2777-2784. http://dx.doi. org/10.1016/j.scitotenv.2010.03.019. PMid:20413147.

Cao, J., Liu, J., Sangbu, D., Yu, S., Zhou, S., Yu, Y., \& Qu, H. (2005). Dental and early-stage skeletal fluorosis in children induced by fluoride in brick-tea. Fluoride, 38, 44-47.

Cao, J., Zhao, Y., \& Liu, J. (1998). Safety evaluation and fluorine concentration of Pu'er brick tea and Bianxiao brick tea. Food and Chemical Toxicology, 36(12), 1061-1063. http://dx.doi.org/10.1016/ S0278-6915(98)00087-8. PMid:9862647.

Castañeda-Saucedo, M. C., Ramírez-anaya, J. P., Tapia-campos, E., \& Diaz-ochoa, E. G. (2020). Comparison of total phenol content and antioxidant activity of herbal infusions with added Stevia reabaudiana Bertoni. Food Science and Technology, 40(1), 117-123. http://dx.doi. org/10.1590/fst.29718.

Castro-González, N. P., Calderón-Sánchez, F., Pérez-Sato, M., SoníGuillermo, E., \& Reyes-Cervantes, E. (2019). Health risk due to chronic heavy metal consumption via cow's milk produced in Puebla, Mexico, in irrigated wastewater areas. Food Additives and Contaminants Part B, Surveillance, 12(1), 38-44. http://dx.doi.org/ 10.1080/19393210.2018.1520742. PMid:30277127.

Chan, L., Mehra, A., Saikat, S., \& Lynch, P. (2013). Human exposure assessment of fluoride from tea (Camellia sinensis L.): A UK based issue? Food Research International, 51(2), 564-570. http://dx.doi. org/10.1016/j.foodres.2013.01.025.

Chen, H., Wang, Q., Jiang, Y., Wang, C., Yin, P., Liu, X., \& Lu, C. (2015). Monitoring and risk assessment of 74 pesticide residues in $\mathrm{Pu}$-erh tea produced in Yunnan, China. Food Additives and Contaminants Part B, Surveillance, 8(1), 56-62. http://dx.doi.org/10.1080/193932 10.2014.972471. PMid:25308103.

Chen, Q., Zhu, Y., Dai, W., Lv, H., Mu, B., Li, P., Tan, J., Ni, D., \& Lin, Z. (2019). Aroma formation and dynamic changes during white tea processing. Food Chemistry, 274, 915-924. http://dx.doi.org/10.1016/j. foodchem.2018.09.072. PMid:30373028.

Dai, W., Xie, D., Lu, M., Li, P., Lv, H., Yang, C., Peng, Q., Zhu, Y., Guo, L., Zhang, Y., Tan, J., \& Lin, Z. (2017). Characterization of white tea metabolome: Comparison against green and black tea by a nontargeted metabolomics approach. Food Research International, 96, 40-45. http://dx.doi.org/10.1016/j.foodres.2017.03.028. PMid:28528106.

Dambiec, M., Polechońska, L., \& Klink, A. (2013). Levels of essential and non-essential elements in black teas commercialized in Poland and their transfer to tea infusion. Journal of Food Composition and Analysis, 31(1), 62-66. http://dx.doi.org/10.1016/j.jfca.2013.03.006.

Emekli-Alturfan, E., Yarat, A., \& Akyuz, S. (2009). Fluoride levels in various black tea, herbal and fruit infusions consumed in Turkey. Food and Chemical Toxicology, 47(7), 1495-1498. http://dx.doi. org/10.1016/j.fct.2009.03.036. PMid:19345715.

Franklin, R., Duis, L., Brown, R., \& Kemp, T. (2005). Trace element content of selected fertilizers and micronutrient source materials. Communications in Soil Science and Plant Analysis, 36(11-12), 15911609. http://dx.doi.org/10.1081/CSS-200059091.

Fu, Q., Liu, Y., Li, L., \& Achal, V. (2014). A survey on the heavy metal contents in Chinese traditional egg products and their potential health risk assessment. Food Additives and Contaminants Part B, 
Surveillance, 7(2), 99-105. http://dx.doi.org/10.1080/19393210.201 3.853106. PMid:24914593.

Fung, K., Zhang, Z., Wong, J., \& Wong, M. (1999). Fluoride contents in tea and soil from tea plantations and the release of fluoride into tea liquor during infusion. Environmental Pollution, 104(2), 197-205. http://dx.doi.org/10.1016/S0269-7491(98)00187-0.

Gardea-Torresdey, J., Peralta-Videa, J., Montes, M., De La Rosa, G., \& Corral-Diaz, B. (2004). Bioaccumulation of cadmium, chromium and copper by Convolvulus arvensis L.: impact on plant growth and uptake of nutritional elements. Bioresource Technology, 92(3), 229-235. http://dx.doi.org/10.1016/j.biortech.2003.10.002. PMid:14766155.

Goenka, P., Sarawgi, A., Karun, V., Nigam, A., Dutta, S., \& Marwah, N. (2013). Camellia sinensis (Tea): Implications and role in preventing dental decay. Pharmacognosy Reviews, 7(14), 152-156. http://dx.doi. org/10.4103/0973-7847.120515. PMid:24347923.

Han, Q., Mihara, S., Hashimoto, K., \& Fujino, T. (2014). Optimization of tea sample preparation methods for ICP-MS and application to verification of Chinese tea authenticity. Food Science and Technology Research, 20(6), 1109-1119. http://dx.doi.org/10.3136/fstr.20.1109.

Han, W., Shi, Y., Ma, L., \& Ruan, J. (2005). Arsenic, cadmium, chromium, cobalt, and copper in different types of Chinese tea. Bulletin of Environmental Contamination and Toxicology, 75(2), 272-277. http:// dx.doi.org/10.1007/s00128-005-0748-2. PMid:16222497.

Han, W., Zhao, F., Shi, J., Ma, Y., \& Ruan, J. (2006). Scale and causes of lead contamination in Chinese tea. Environmental Pollution, 139(1), 125-132. http://dx.doi.org/10.1016/j.envpol.2005.04.025. PMid:15998560.

Janiszewska, J., \& Balcerzak, M. (2013). Analytical problems with the evaluation of human exposure to fluorides from tea products. Food Analytical Methods, 6(4), 1090-1098. http://dx.doi.org/10.1007/ s12161-012-9514-3.

Jiang, D., Li, F., Zheng, F., Zhou, J., Li, L., Shen, F., Chen, J., \& Li, W. (2019). Occurrence and dietary exposure assessment of multiple mycotoxins in corn-based food products from Shandong, China. Food Additives and Contaminants Part B, Surveillance, 12(1), 10-17. http://dx.doi.org/10.1080/19393210.2018.1503341. PMid:30035665.

Jin, C., Zheng, S., He, Y., Zhou, G., \& Zhou, Z. (2005). Lead contamination in tea garden soils and factors affecting its bioavailability. Chemosphere, 59(8), 1151-1159. http://dx.doi.org/10.1016/j.chemosphere.2004.11.058. PMid:15833489.

Karak, T., \& Bhagat, R. M. (2010). Trace elements in tea leaves, made tea and tea infusion: a review. Food Research International, 43(9), 2234-2252. http://dx.doi.org/10.1016/j.foodres.2010.08.010.

Khan, M. U., Malik, R. N., \& Muhammad, S. (2013). Human health risk from heavy metal via food crops consumption with waste-water irrigation practices in Pakistan. Chemosphere, 93(10), 2230-2238. http://dx.doi.org/10.1016/j.chemosphere.2013.07.067. PMid:24075531.

Koblar, A., Tavčar, G., \& Ponikvar-Svet, M. (2012). Fluoride in teas of different types and forms and the exposure of humans to fluoride with tea and diet. Food Chemistry, 130(2), 286-290. http://dx.doi. org/10.1016/j.foodchem.2011.07.037.

Li, P., Kong, S., Geng, C., Han, B., Lu, B., Sun, R., Zhao, R., \& Bai, Z. (2013). Assessing the hazardous risks of vehicle inspection workers' exposure to particulate heavy metals in their work places. Aerosol and Air Quality Research, 13(1), 255-265. http://dx.doi.org/10.4209/ aaqr.2012.04.0087.

Li, Y., Lei, J., Yang, J., \& Liu, R. (2014). Classification of Tieguanyin tea with an electronic tongue and pattern recognition. Analytical Letters, 47(14), 2361-2369. http://dx.doi.org/10.1080/00032719.2014.908381.
Lv, H., Lin, Z., Tan, J., \& Guo, L. (2013). Contents of fluoride, lead, copper, chromium, arsenic and cadmium in Chinese Pu-erh tea. Food Research International, 53(2), 938-944. http://dx.doi.org/10.1016/j. foodres.2012.06.014.

Malinowska, E., Inkielewicz, I., Czarnowski, W., \& Szefer, P. (2008). Assessment of fluoride concentration and daily intake by human from tea and herbal infusions. Food and Chemical Toxicology, 46(3), 10551061. http://dx.doi.org/10.1016/j.fct.2007.10.039. PMid:18078704.

Natesan, S., \& Ranganathan, V. (1990). Content of various elements in different parts of the tea plant and in infusions of black tea from southern India. Journal of the Science of Food and Agriculture, 51(1), 125-139. http://dx.doi.org/10.1002/jsfa.2740510112.

Ning, J., Ding, D., Song, Y., Zhang, Z., Luo, X., \& Wan, X. (2016). Chemical constituents analysis of white tea of different qualities and different storage times. European Food Research and Technology, 242(12), 2093-2104. http://dx.doi.org/10.1007/s00217-016-2706-0.

Ning, P., Gong, C., Zhang, Y., Guo, K., \& Bai, J. (2011). Lead, cadmium, arsenic, mercury and copper levels in Chinese Yunnan Pu'er tea. Food Additives and Contaminants Part B, Surveillance, 4(1), 28-33. http://dx.doi.org/10.1080/19393210.2011.551945. PMid:24779659.

Nkansah, M., Opoku, F., \& Ackumey, A. (2016). Risk assessment of mineral and heavy metal content of selected tea products from the Ghanaian market. Environmental Monitoring and Assessment, 188(6), 332. http://dx.doi.org/10.1007/s10661-016-5343-y. PMid:27154053.

Nookabkaew, S., Rangkadilok, N., \& Satayavivad, J. (2006). Determination of trace elements in herbal tea products and their infusions consumed in Thailand. Journal of Agricultural and Food Chemistry, 54(18), 6939-6944. http://dx.doi.org/10.1021/jf060571w. PMid:16939361.

Pehrsson, P., Patterson, K., \& Perry, C. (2011). The fluoride content of select brewed and microwave-brewed black teas in the United States. Journal of Food Composition and Analysis, 24(7), 971-975. http://dx.doi.org/10.1016/j.jfca.2010.12.013.

Qin, F., \& Chen, W. (2007). Lead and copper levels in tea samples marketed in Beijing, China. Bulletin of Environmental Contamination and Toxicology, 79(3), 247-250. http://dx.doi.org/10.1007/s00128007-9008-y. PMid:17639336.

Rasmussen, P. E., Subramanian, K. S., \& Jessiman, B. J. (2001). A multielement profile of house dust in relation to exterior dust and soils in the city of Ottawa, Canada. The Science of the Total Environment, 267(1-3), 125-140. http://dx.doi.org/10.1016/S0048-9697(00)007750. PMid:11286208.

Roya, A., \& Ali, M. (2017). Heavy metals in rice samples on the TorbatHeidarieh market, Iran. Food Additive and Contaminations Part B, Surveillance, 10(1), 59-63. http://dx.doi.org/10.1080/19393210.20 16.1247918. PMid:27782775.

Salahinejad, M., \& Aflaki, F. (2010). Toxic and essential mineral elements content of black tea leaves and their tea infusions consumed in Iran. Biological Trace Element Research, 134(1), 109-117. http://dx.doi. org/10.1007/s12011-009-8449-z. PMid:19609493.

Sanlier, N., Atik, İ., \& Atik, A. (2018). A minireview of effects of white tea consumption on diseases. Trends in Food Science \& Technology, 82, 82-88. http://dx.doi.org/10.1016/j.tifs.2018.10.004.

Seenivasan, S., Manikandan, N., Muraleedharan, N., \& Selvasundaram, R. (2008). Heavy metal content of black teas from south India. Food Control, 19(8), 746-749. http://dx.doi.org/10.1016/j.foodcont.2007.07.012.

Sha, J., \& Zheng, D. (1994). Study on the fluorine content in fresh leaves of tea planted in Fujian Province. Chaye Kexue, 14, 37-42. In Chinese.

Shen, F., \& Chen, H. (2008). Element composition of tea leaves and tea infusions and its impact on health. Bulletin of Environmental 
Contamination and Toxicology, 80(3), 300-304. http://dx.doi. org/10.1007/s00128-008-9367-z. PMid:18309449.

Shokrzadeh, M., Saberyan, M., \& Saeedi Saravi, S. S. (2008). Assessment of lead $(\mathrm{Pb})$ and cadmium $(\mathrm{Cd})$ in 10 samples of Iranian and foreign consumed tea leaves and dissolved beverages. Toxicological and Environmental Chemistry, 90(5), 879-883. http://dx.doi. org/10.1080/02772240701770731.

Shu, W., Zhang, C., Lan, C., \& Wong, M. (2003). Fluoride and aluminum concentrations of tea plants and tea products from Sichuan Province, P.R. China. Chemosphere, 52(9), 1475-1482. http://dx.doi.org/10.1016/ S0045-6535(03)00485-5. PMid:12867178.

Standardization Administration of China - SAC. (2003). GB/T 5009.182003: determination of fluorine in foods. Beijing: Standards Press of China. (in Chinese).

Standardization Administration of China - SAC. (2013). GB/T 83022013: tea sampling. Beijing: Standards Press of China. (in Chinese).

Takahashi, K., Akiniwa, K., \& Narita, K. (2001). Regression analysis of cancer incidence rates and water fluoride in the U.S.A. based on IACR/IACR (WHO) data (1978-1992). International Agency for Research on Cancer. Journal of Epidemiology, 11(4), 170-179. http:// dx.doi.org/10.2188/jea.11.170. PMid:11512573.

Tan, J., Engelhardt, U., Lin, Z., Kaiser, N., \& Maiwald, B. (2017). Flavonoids, phenolic acids, alkaloids and theanine in different types of authentic Chinese white tea samples. Journal of Food Composition and Analysis, 57, 8-15. http://dx.doi.org/10.1016/j. jfca.2016.12.011.

Tian, L., \& Huang, J. (2019). Antioxidant effects of tea catechins on the shelf life of raw minced duck meat. Food Science and Technology, 39(1), 59-65. http://dx.doi.org/10.1590/fst.25217.

United States Environmental Protection Agency - US-EPA. (2002). Supplemental guidance for developing soil screening levels for superfund sites office of solid waste and emergency response. Washington: US-EPA. Retrieved from https://rais.ornl.gov/documents/SSG_ nonrad_supplemental.pdf

United States Environmental Protection Agency - US-EPA. (2016). Guidelines for carcinogen risk assessment. Washington: US-EPA. Retrieved from https://www3.epa.gov/airtoxics/cancer_guidelines_ final_3-25-05.pdf

Waugh, D., Godfrey, M., Limeback, H., \& Potter, W. (2017). Black tea source, production, and consumption: assessment of health risks of fluoride intake in New Zealand. Journal of Environmental and Public Health, 2017, 5120504. http://dx.doi.org/10.1155/2017/5120504. PMid:28713433.

World Health Organization - WHO. (1984). Fluorine and fluoride (Environmental Health Criteria, No. 36). Geneva: WHO.

Xu, Y., Liu, P., Shi, J., Gao, Y., Wang, Q., \& Yin, J. (2018). Quality development and main chemical components of Tieguanyin oolong teas processed from different parts of fresh shoots. Food Chemistry,
249, 176-183. http://dx.doi.org/10.1016/j.foodchem.2018.01.019. PMid:29407922.

Yaqub, G., Ilyas, F., Idrees, M., \& Mariyam, V. (2018). Monitoring and risk assessment due to presence of heavy metals and pesticides in tea samples. Food Science and Technology, 38(4), 625-628. http:// dx.doi.org/10.1590/fst.07417.

Yemane, M., Chandravanshi, B., \& Wondimu, T. (2008). Levels of essential and non-essential metals in leaves of the tea plant (Camellia sinensis L.) and soil of Wushwush farms, Ethiopia. Food Chemistry, 107, 1236-1243.

Yen, W., Chyau, C., Lee, C., Chu, H., Chang, L., \& Duh, P. (2013). Cytoprotective effect of white tea against $\mathrm{H}_{2} \mathrm{O}_{2}$-induced oxidative stress in vitro. Food Chemistry, 141(4), 4107-4114. http://dx.doi. org/10.1016/j.foodchem.2013.06.106. PMid:23993592.

Yi, Z., Guo, P., Zheng, L., Huang, X., \& Bi, J. (2013). Distribution of $\mathrm{HCH}$ and DDTs in the soil-plant system in tea gardens in Fujian, a major tea-producing province in China. Agriculture, Ecosystems \& Environment, 171, 19-24. http://dx.doi.org/10.1016/j.agee.2013.03.002.

Zhang, H., Jiang, Y., Lv, Y., Pan, J., Duan, Y., Huang, Y., Zhu, Y., Zhang, S., \& Geng, K. (2017a). Effect of water quality on the main components in Fuding white tea infusions. Journal of Food Science and Technology, 54(5), 1206-1211. http://dx.doi.org/10.1007/s13197-017-2571-2. PMid:28416871.

Zhang, R., Zhang, H., Chen, Q., Luo, J., Chai, Z., \& Shen, J. (2017b). Composition, distribution and risk of total fluorine, extractable organofluorine and perfluorinated compounds in Chinese teas. Food Chemistry, 219, 496-502. http://dx.doi.org/10.1016/j. foodchem.2016.09.136. PMid:27765257.

Zhang, J., Yang, R., Chen, R., Peng, Y., Wen, X., \& Gao, L. (2018). Accumulation of heavy metals in tea leaves and potential health risk assessment: a case study from Puan county, Guizhou province, China. International Journal of Environmental Research and Public Health, 15(1), 133. http://dx.doi.org/10.3390/ijerph15010133. PMid:29342877.

Zhang, X., Peng, Y., \& Wang, Q. (2019). Study on the browning and structure properties of fresh-cut Chinese water chestnut (Eleocharis tuberosa). Food Science and Technology, 39(2), 396-402. http://dx.doi. org/10.1590/fst.28917.

Zhao, Y., Chen, P., Lin, L., Harnly, J., Yu, L., \& Li, Z. (2011). Tentative identification, quantitation, and principal component analysis of green pu-erh, green, and white teas using UPLC/DAD/MS. Food Chemistry, 126(3), 1269-1277. http://dx.doi.org/10.1016/j. foodchem.2010.11.055. PMid:25544798.

Zhou, P., Hu, O., Fu, H., Ouyang, L., Gong, X., Meng, P., Wang, Z., Dai, M., Guo, X., \& Wang, Y. (2019). UPLC-Q-TOF/MS-based untargeted metabolomics coupled with chemometrics approach for Tieguanyin tea with seasonal and year variations. Food Chemistry, 283, 73-82. http://dx.doi.org/10.1016/j.foodchem.2019.01.050. PMid:30722928. 